\title{
Criminal Procedural Code of the Russian Federation: evaluation of effectiveness and measures for its improvement
}

\author{
BORIS YA. GAVRILOV \\ Academy of Management of the Ministry of Internal Affairs of Russia, Moscow, \\ Russian Federation \\ ORCID: https://orcid.org/0000-0002-2529-491X, e-mail: profgavrilov@yandex.ru
}

\begin{abstract}
Introduction: the article analyzes provisions of the Criminal Procedural Code of the Russian Federation and its impact on the implementation of key legal institutions designed to ensure respect for the rights and legitimate interests of criminal proceedings participants by law enforcement and judicial authorities. Purpose: having studied effectiveness of the amendments made in the CPC and conducted statistical analysis of the results of criminal cases investigation, the author presents shortcomings in the legislation identified by the scientific community and law enforcement practice and proposes measures to improve both certain legal norms of the CPC RF and its procedural institutions in order to ensure constitutional provisions on the state protection of human and civil rights and freedoms. Methods: the researcher used historical, comparative legal and empirical methods for describing quality and legality issues in the investigation of criminal cases; theoretical methods of formal and dialectical logic. Private scientific and legal technical methods, as well as the method for interpreting specific legal norms were applied. Results: the analysis of development of Russian and foreign criminal procedural legislation and law enforcement practice objectively indicates that the absolute majority of the amendments made to the Code contributed to enhancing performance of pre-trial investigation or initial inquiry bodies in implementing the provisions of Article 6 of the CPC. It stipulates protection of the rights and lawful interests of the persons and organizations, who (which) have suffered from the crimes, as well as their protection from unlawful accusations and conviction, and other restrictions of their rights and freedoms. Betterment of the criminal procedural legislation is also aimed at overcoming formalization of its individual provisions and bureaucratization of actions of the inquirer, investigator, prosecutor's office and judicial community in the investigation and trial of criminal cases. Conclusions: to adapt the modern Russian criminal process to modern realities (new types of crimes and methods of their commission, increased requirements for ensuring legality in activities of pre-trial investigation bodies, their compliance with procedural deadlines in criminal cases and improving investigation quality) it is necessary to make changes in pre-trial proceedings, in particular, to reorganize procedural rules for commencement of criminal proceedings; bringing investigation terms into line with the provisions of Article 61 of the $\mathrm{CPC}$ on a reasonable period of criminal proceedings; differentiating investigation forms, etc. All this is focused on improving effectiveness of the fight against crime and its most dangerous types.

Ke y w o rd s: pre-trial proceedings; criminal case; procedural deadlines; legality and quality of investigation; improvement of legislation.
\end{abstract}

12.00.09 - Criminal process.

F or c it at i o n: Gavrilov B.Ya. Criminal Procedural Code of the Russian Federation: evaluation of effectiveness and measures for its improvement. Penitentiary Science, 2021, vol. 15, no. 4 (56), p. 868-877. DOI 10.46741/2686-9764-2021-15-4-868-877.

\section{Introduction}

The article presents the author's vision of progressive development of the Russian criminal procedure legislation with regard to the amendments made to the Criminal Procedural Code for 20 years of its operation by more than 280 federal laws to both individual procedural norms and entire institutions. They include pro- 
cedural rules on the possibility of conducting more than 10 investigative and other procedural actions at the stage of verifying allegations, separation of investigative bodies from the prosecutor's office and formation of the Investigative Committee of the Russian Federation, differentiation of procedural powers between the prosecutor and the head of the investigative body, introduction of inquiry department and inquiry body heads, etc. into the number of participants in criminal proceedings for the prosecution, as well as analysis of the CPC effectiveness monitoring results and opinions of leading Russian processualists and practitioners (investigators and inquirers).

\section{Discussion}

The author considers the current state of the criminal procedural legislation by taking into account the effectiveness of implementing provisions of Article 6 of the Criminal Procedural Code of the Russian Federation on the purpose of criminal proceedings, designed to protect the rights and legitimate interests of both persons and organizations affected by crimes, and the individual from unlawful and unjustified accusations and convictions, as well as restrictions on his/her rights and freedoms.

The author pays special attention to disputability of the content of the CPC RF key provisions. At the same time, the introduction of such a significant number of amendments to the Code over 20 years indicates that the law has certain shortcomings, which, in turn, gives rise to numerous critical statements on the part of processualists and practicing lawyers.

So, Professor L.V. Golovko, describing the CPC RF adopted in 2001, notes that the Code "has not only stabilized the domestic criminal process of the post-Soviet model, but rather "blurred" and destabilized it. At the same time, attributing the "blurring effect" to a certain "dynamism" inherent in our time, in his opinion, is not reasonable, since it is far from the truth, just as claims for some special dynamism of our time" [13, p. 3-5].

However, we cannot agree with this statement, as he addressed legislation issues in the late 1980s, when it "took years" to prepare and adopt bills. We believe that such a great number of changes to the criminal procedure legislation is, on the one hand, due to significantly increased needs of law enforcement practice in terms of improving procedural rules of preliminary investigation and trial and, on the other hand, rapid development of legal relations in the field of criminal proceedings.
Adoption of the Federal Law No. 87-FZ of June 5, 2007 "On amendments to the Criminal Procedural Code of the Russian Federation and the Federal Law on the Prosecutor's Office of the Russian Federation" is a classic example of amending the CPC RF to meet the needs of law enforcement. According to it, investigators of the prosecutor's office were divested from prosecutors' subordination, and in this regard, the procedural powers to direct the investigation were transferred from the prosecutor to the head of the investigative body, while retaining its supervisory function in full. The need for this has been repeatedly expressed by scientific community representatives, and on the eve of this reform the leadership of the Prosecutor General's Office of the Russian Federation made a report to Russian President Vladimir Putin, where recognized the need to assign powers for procedural management of investigation and its supervision to two deputies Prosecutor Generals of the Russian Federation, which would require the implementation of this proposal at the district level. It resulted in the refusal to implement this already at the stage of preparation of the relevant order by the Prosecutor General's Office of Russia.

The same law excludes from the CPC the prosecutor's powers to coordinate the decision of an official of pre-trial investigation and initial inquiry bodies on initiation of a criminal case. Five-year enforcement of this provision had a negative impact on activities of the investigator and inquirer in terms of timely initiation of criminal proceedings and limited the ability to collect evidence in order to solve crimes in hot pursuit. The prosecutor was deprived of the right to initiate criminal proceedings, which, as law enforcement practice shows, he used in isolated cases.

The need to reform this part of pre-trial proceedings is justified by the following statistics on results of the investigation work to implement provisions of the Federal Law No. 87-FZ that indicate a higher level of procedural control, reflected in:

a) improved indicators of legality in pre-trial investigation body activities, the significant reduction in the number of persons acquitted by the court, including those in custody (Figure 1);

b) strengthening the prosecutor's function to monitor investigation quality, the increased number of criminal cases returned by the prosecutor to investigators of both internal affairs bodies and of the Investigative Committee of the Russian Federation (Figure 2); 


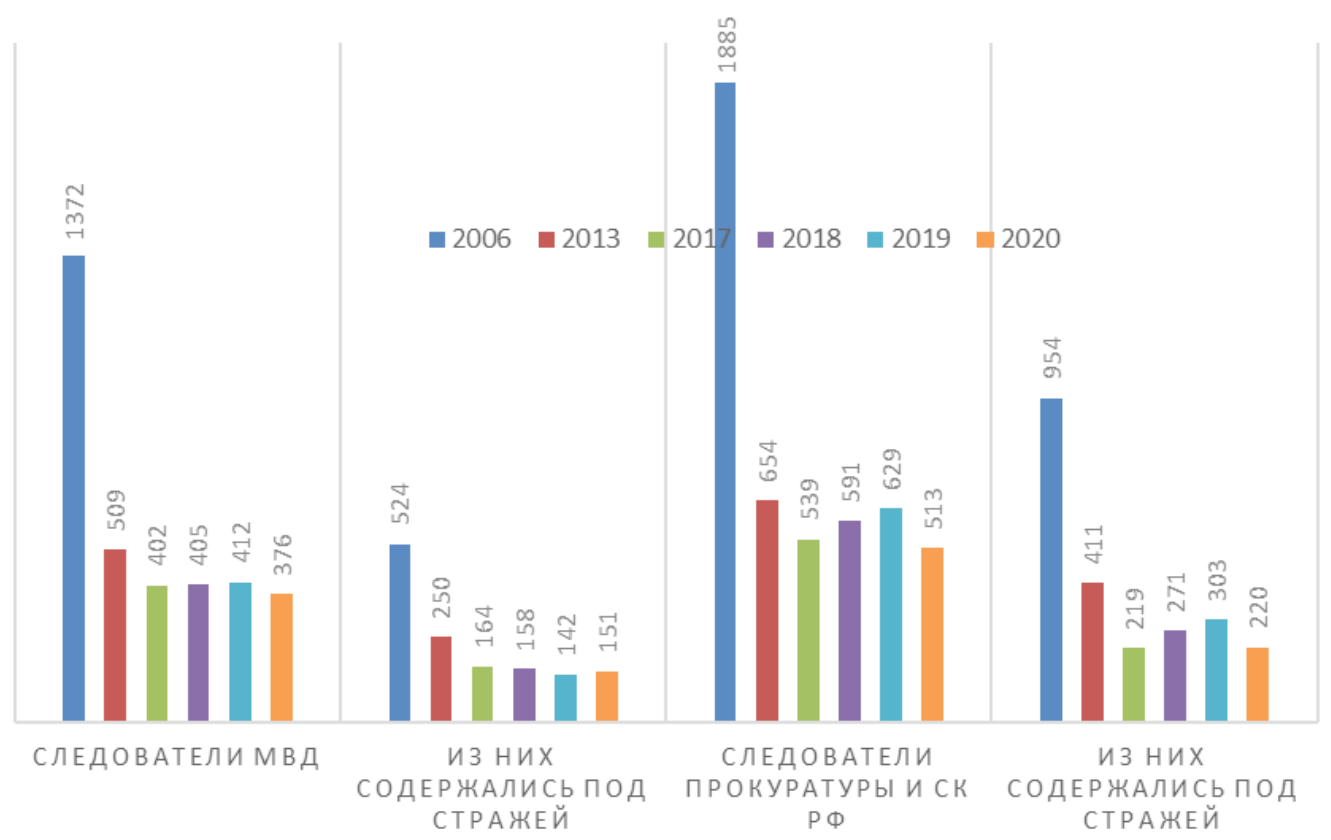

Figure 1. Data on the number of persons acquitted by the court and unlawfully detained (for 2006,2013, 2017-2020) (Invest. of int. affairs bodies, Of them in custody, Invest. of the Prosec. and IC RF, Of them in custody)

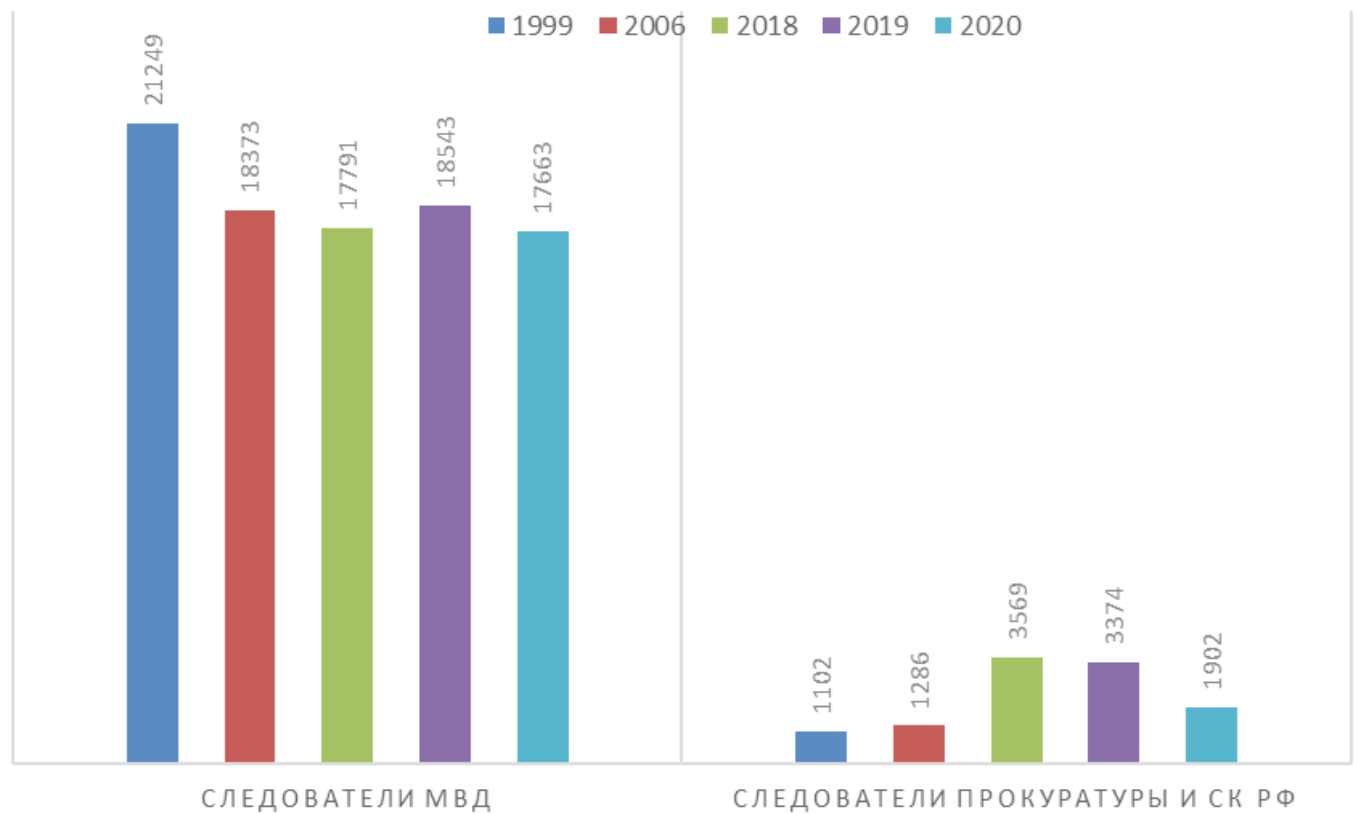

Figure 2. Number of criminal cases returned by the prosecutor for further investigation (Invest. of int. affairs bodies, Invest. of the Prosec. and IC RF)

c) ensuring a reduction in the number of cases returned by the court to the prosecutor in accordance with Article 237 of the CPC RF (Figure 3) [8].

What is more, Professor L.V. Golovko, speaking about the quality of criminal procedural legislation, notes that any codification terminates the old legal order and generates a new one, which is associated with the quality of the crimi- nal procedure codification itself, but the latter is extremely eclectic and unsuccessfully tries to copy Anglo-American approaches a priori incompatible with the Russian legal system, which seek to present the criminal process as a market "competition" between the state and its citizens [13].

The above hypothesis, supported by a number of Russian scientists, is not proved by any 


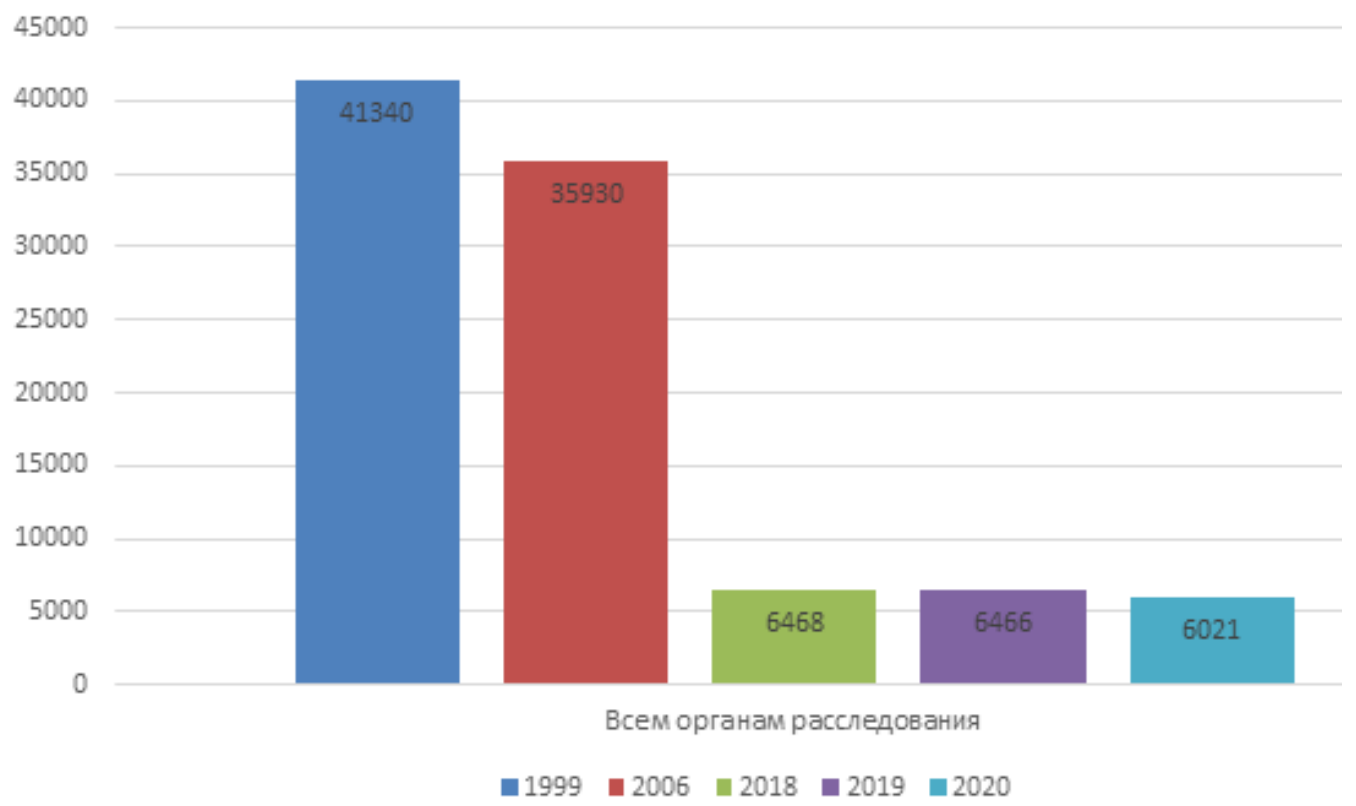

Figure 3. Number of cases returned by the court for further investigation (before July 1, 2002) and by the court to the prosecutor in accordance with Article 237 of the CPC RF to all investigation bodies

arguments. Although, indeed, at the suggestion of one of the members of the working group, the draft Code included a norm (Part 6 of Article 234 of the CPC RF as amended in 2001), borrowed from the procedural legislation of the United States, on the impossibility of satisfying a motion filed by the defense during the trial to summon an investigator to establish the defendant's alibi, if this motion was made at the preliminary investigation and was rejected. However, this norm was soon excluded from the CPC RF.

At the same time, the author shares the opinion of S.B. Rossinskii that legislative trends are often aimed at "hyperformalization of criminal procedure law, in an effort to "legitimize" (in a narrow sense) a wider range of rules of conduct applied during the preliminary investigation and trial than common sense requires, turning the CPC into a kind of administrative regulation" $[19$, p. 42].

At the same time, the analysis of the amendments made to the Code for over the 20 years of its operation suggests that they pursued the goal to comply with decisions of the Constitutional Court of the Russian Federation, the European Court of Human Rights (hereinafter - the ECHR) and, as noted above, demand of law enforcement officers. At the same time, we cannot but agree that some amendments to the CPC RF were of a populist nature, proposed primarily by legislative authorities. Some of them, including those introduced by the highest judicial instance of the country, were counter-reforms due to their inconsistency with a number of fundamental provisions of the adopted CPC RF, for instance, on the procedure for presenting evidence in the indictment, actual expansion of the institution of returning a criminal case to the prosecutor [8]. In fact, Professor V.P. Bozh'ev expressed a similar opinion about the Constitutional Court of the Russian Federation [3].

We observe a great number of amendments to the CPC RF, as legislators had to make compromise decisions when preparing and adopting the Code, since at that time the proposals of members of the working group under the State Duma Committee on Legislation were not realized in terms of differentiation of procedural powers between the prosecutor and the head of the investigative body on changing procedural rules for the initiation of investigation, introducing the head of the inquiry department into pre-trial proceedings and a number of other changes that the legislator was forced to implement in the following years [10].

Among the factors that led to the introduction of such a significant number of changes to the CPC RF, we can single out an inconsistent position of the legislator, who retained the prosecutor the right to authorize investigative actions that restrict constitutional rights of citizens, including detention, up to January 1, 2004 by the Federal Law No. 177-FZ of December 18, 2001 "On the enactment of the Criminal Procedural 
Code of the Russian Federation" and grant the Prosecutor General of the Russian Federation and his deputies the right to extend periods of custody by the Federal Law No. 183-FZ of December 29, 2001 "On amendments to Article 97 of the Criminal Procedual Code of the RSFSR". The Constitutional Court of the Russian Federation in its Resolution No. 6-P of March 14, 2002 "On the case of inspecting constitutionality of Articles 90, 96, 122 and 216 of the Criminal Procedural Code of the RSFSR in connection with complaints of citizens of S.S. Martynov and S.V. Pustovalov" recognized the above provisions as inconsistent with Articles 21, 22, 23, 25 of the Constitution of the Russian Federation, which required the legislator to make a whole block of relevant amendments to the CPC RF even before its entry into force (Federal Law No. 58FZ of May 29, 2002 "On amendments and additions to the Criminal Procedural Code of the Russian Federation").

The need for the Russian Federation to comply with a number of decisions of the European Court of Human Rights is also worth mentioning. Thus, the Federal Law No. 69-FZ of April 30, 2010 "On amendments to certain legislative acts of the Russian Federation in connection with the adoption of the Federal Law "On compensation for violation of the right to a reasonable period of legal proceedings or the right to execute a judicial act within a reasonable time" included the norm-principle - Article 6.1 of the CPC RF "A reasonable period of criminal proceedings", which implemented the decisions of the ECHR of January 15, 2009 in the case of "Burdov" and "Burdov vs. the Russian Federation (No. 2)" (complaint No. 33509/04). And only this one norm (Article 6.1 of the CPC RF) was subsequently amended by five federal laws in order to clarify the time of calculating reasonable deadlines, which generally indicates the real need for numerous changes to the Code.

As noted above, the absolute majority of amendments were due to the needs of law enforcement practice.

At the same time, the analysis of CPC RF application effectiveness in pre-trial proceedings indicates the need for further reforming: it primarily concerns the stage of initiation of a criminal case, the presence of which caused a twofold decrease in the number of criminal cases initiated in 2020 in relation to 2006 . The number of procedural decisions of the investigator, inquirer, inquiry body on refusal to initiate criminal proceedings increased by 2.3 million cases over this period, while the number of reported crimes decreased slightly [4]. This procedural activity actually restricts the citizens' right to access to justice and compensation for the damage caused to them by the crime committed (Article 52 of the Constitution of the Russian Federation) (Figure 4).

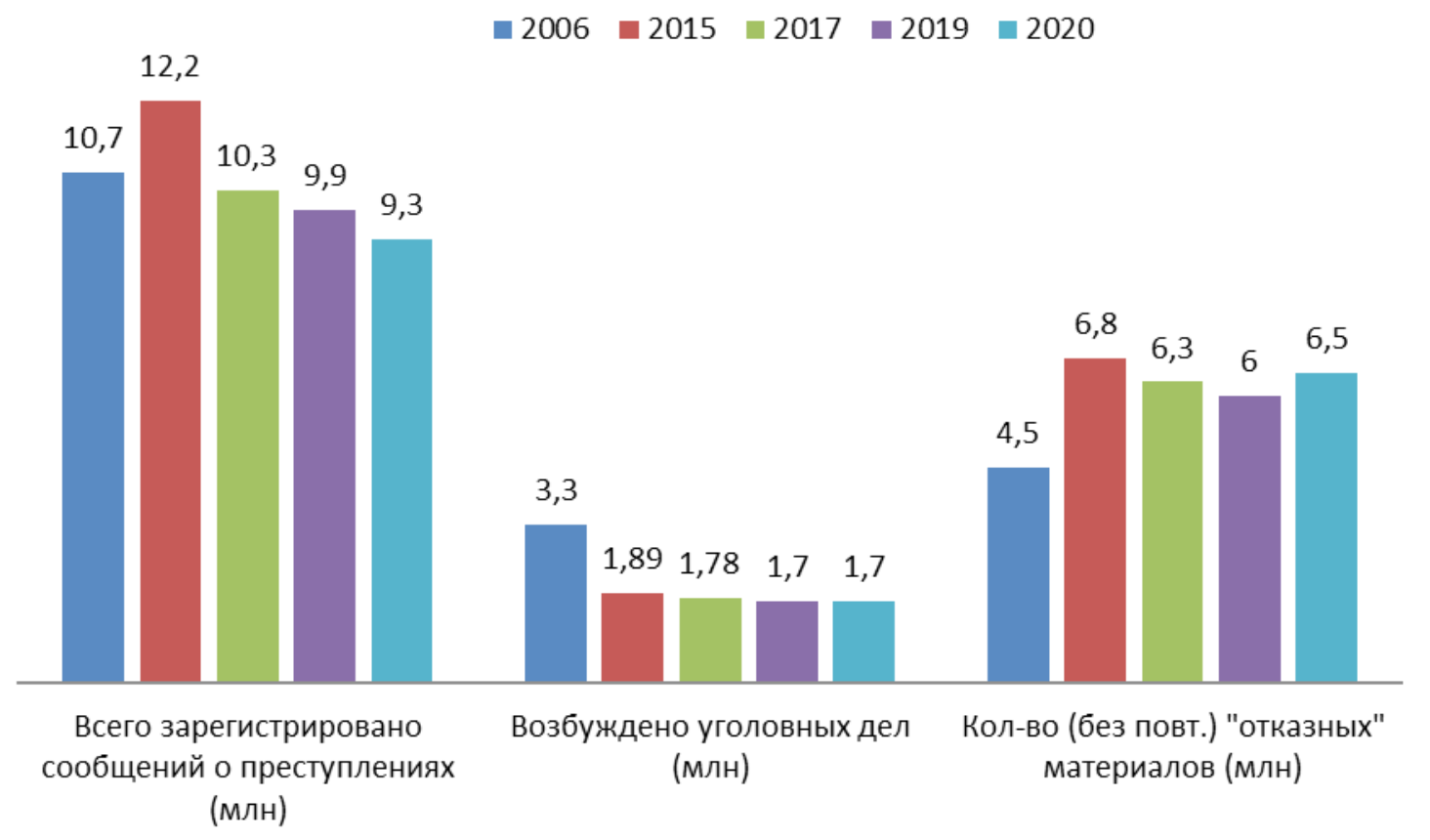

Figure 4. Data on the number of reported crimes and decisions taken on them (for 2006, 2015, 2017, 2019-2020)

(Total reports of crimes registered (million), Criminal cases initiated (million), Number of rejected cases (without repetitions) (million)) 
The author's proposals, supported by other scientists [12; 16], on the exclusion of Articles 146 and 148 of the CPC RF are made with regard to the decisions of the Constitutional Court of the Russian Federation (ruling No. 343 of July 18, 2006 "On refusal to accept for consideration the complaint of citizen Lazaryants Andrei Emmanuilovich on violation of his constitutional rights by Articles 241 and 242 of the Criminal Code of the Russian Federation, part one of Article 46, Articles 57, 80, part one of Article 108, Articles 171, 172 and 195 of the Criminal Procedural Code of the Russian Federation") and the position of the Supreme Courts of the Russian Federation, marked V.V. Kozhokar' [14]. According to it, when a new episode of criminal activity is detected in a criminal case under investigation or an accomplice is identified, the investigator must initiate a new criminal case, which is subsequently combined with the main criminal case, which contradicts the previously adopted decisions of these judicial authorities, as well as the long-term practice of investigation and the legal content of the norm on initiating a criminal case that has remained unchanged for 60 years.

At the same time, there are other points of view that support preservation of the stage of initiation of a criminal case [6; 21] or expressing a more neutral position [5; 17].

As noted above, in subsequent years to meet the demands of the law enforcement, the Federal Law No. 23-FZ of March 4, 2013 "On amendments to Articles 62 and 303 of the Criminal Code of the Russian Federation and the Criminal Procedural Code of the Russian Federation" significantly expanded the list of investigative and other proceedings that could be initiated during verification of allegations and due to reports of a crime, in particular: obtaining explanations and samples for comparative research, reclamation of objects and documents, assignment and conduct of forensic examination, etc. It empowered investigators, inquirers, and other officials of inquiry bodies to collect evidence at the stage of initiating a criminal case. This law also introduced a concise form of inquiry into pre-trial proceedings, which provides for the possibility of investigating in a shorter time and collecting evidence in the amount sufficient to carry out legal proceedings in a criminal case.

Provision of quality investigation in the form of an inquiry in a general manner and in a concise form is stipulated by the Federal Law No. 90-FZ of June 6, 2007 "On amendments to the
Criminal Procedural Code of the Russian Federation", which introduced a head of the inquiry department, and subsequently a head of the inquiry body as a criminal process participant, institute of pre-trial cooperation agreement and a number of other changes.

Along with pre-trial proceedings, judicial proceedings have also undergone significant changes. Thus, since January 1, 2013, the appellate procedure for reviewing sentences has been extended to federal courts, since June 1, 2018, jurisdiction of the jury court - to federal courts of district and city levels, and since October 31, 2019, five appeal and nine cassation courts of general jurisdiction have been included in the judicial system in order to increase the level of ensuring the rights and legitimate interests of participants in criminal proceedings.

At the same time, when building a model of the modern Criminal Procedural Code of the Russian Federation, representatives of the scientific community, law enforcement officers and legislators failed to overcome formalization and bureaucratization of the criminal procedural law that had already developed within the framework of the Criminal Procedural Code of the RSFSR, involving low efficiency of pre-trial proceedings. We have made this conclusion on the basis that the number of criminal cases sent to court by, for example, investigators of internal affairs bodies from among the number of initiated ones decreased by more than a third (from $36 \%$ in 1991 up to $22 \%$ in 2020) (for example, the Verdict of the Bogoroditskii District Court of the Tula Oblast No. 1-1/2016 1-124/2015 of January 18, 2016 in the case No. 1-1/2016) [9; 11].

Professor A.S. Aleksandrov [2] assesses this state of criminal proceedings as a fundamental defect of the domestic legal model and suggests abandoning pre-trial investigation with the transition to a "prosecutor's" inquiry. It would be possible to agree with this statement if the judicial system were ready for this. Moreover, such revolutionary transformations in Russian conditions can destroy the system of preliminary investigation, without which the judicial system will have nothing to do. For the same reason, the proposals on introducing a lawyer (parallel) investigation were not approved.

The need to improve the criminal procedure legislation is due, as noted above, to the fact that the overall effectiveness of criminal proceedings does not meet the requirements of today, requires a review of individual procedural institutions. 
These changes should be directed to:

- bring the provisions of Article 162 of the CPC RF, which grants pre-trial investigation bodies the right to extend the period of preliminary investigation without its limitation, in accordance with the norm-principle (Article 6.1 of the CPC RF) on a reasonable length of criminal proceedings, which, based on the content of the Resolution of the Plenum of the Supreme Court of the Russian Federation No. 11-P dated March 29, 2016 shall not exceed four years in criminal cases. The provision of part one of Article 162 of the CPC RF on the two-month initial period of investigation, transferred from the CPC RSFSR adopted in 1922 also needs revision;

- increase the initial (two months) period for holding the accused in custody: according to the provisions of Part 1 and Part 1.1 of Article 221 of the CPC RF, it shall take the prosecutor 10-30 days to approve the indictment on the criminal case (instead of 5 days under the CPC RF as amended in 2001) and the court (judge) another 14 days to make a relevant decision in accordance with Part 1 of Article 227 of the CPC RF. This proposal also takes into account the experience of countries with an entrenched justice system, where the initial period of detention of a person is from 120 to 180 days, and according to the Criminal Procedural Code of Italy - 6 months with the possibility of its reduction by the court at the request of the prosecutor or the defense;

- revise procedural rules for preferment of charges, the norms of which for decades ensured the accused's right to defense by allowing a lawyer to participate in a criminal case from the moment of filing accusation. However, today, with the adoption of the above-mentioned Federal Law No. 23-FZ, the participation of a defender is provided already from the moment of verification of a crime report against a person, that is, even before the initiation of a criminal case. In the current CPC RF there are virtually no differences in the legal status of the suspected (Article 46) and the accused (Article 47 ) with the exception of the completion stage of a criminal case. We consider it an argument that more than 5 million criminal cases investigated in the form of an inquiry have been sent to court without a classic charge. At the same time, none of the convicts appealed either to the Constitutional Court of the Russian Federation or to the European Court of Human Rights with a complaint about the restriction of their constitutional right to protection from prosecution. It is also necessary to take into account the position of the ECHR in the Eckle case (Decision of August 15, 1982 in the "Eckle case against the Federal Republic of Germany" (Complaint No. 8130/78)) and a number of its other decisions that accusation is a reasonable suspicion that allows criminal prosecution on behalf of the state.

In turn, S.B. Rossinskii draws attention to the fact that in the pre-revolutionary legislation of Russia the accused was understood as a certain subject against whom a pre-trial investigation was carried out in order to establish their involvement in the crime. And their appearance in the criminal case was not predetermined by the initiation of a special investigative act. In other words, the position of the pre-revolutionary accused more closely resembled that of today's suspects $[17 ; 18]$. The institution of indictment appeared in the Criminal Procedural Code of the RSFSR in 1922, the second section of which contained a special chapter 9 "Indictment and inquiry" [15].

Reorganization of the indictment institution is directly related to the issue of the court's powers to change the charges, which for decades has served as the main means of eliminating errors and shortcomings of pre-trial investigation. Under the CPC RSFSR the court annually returned 45-56 thousand criminal cases to investigators and inquirers to conduct further investigation, which negatively affected the length of investigation and subsequent trial, increasing it from three to six months, and in individual criminal cases from 1.5 to 2 years. Besides, it was impossible to change charge for a more serious one in court.

When developing proposals to improve this institution, we proceed from the fact that direct correction of defects and inconsistencies with established facts in court is allowed by the legislation and judicial practice of England, Wales and Scotland and other states. For example, in Italy, during a judicial investigation, the prosecutor, while respecting the right of the accused to defense and other conditions, is entitled to change the original charge to a more serious one or significantly different from the original one by additional notification or a new statement of the act (Articles 517, 519 of the Italian Criminal Procedural Code). According to Article 732 of the Spanish Criminal Procedural Law, the prosecution may amend the conclusions in the writs of classification. It is an independent stage of the trial, in which, in order to strengthen the prosecution, it is provided for postponing the hearing of the case at the request of 
the defense to prepare evidence to refute the amended charge. The possibility of changing the charges in the trial to a more serious one without returning the criminal case to the prosecutor is provided for in Article 301 of the CPC of the Republic of Belarus and Article 340-341 of the CPC of Kazakhstan.

We, as well as other scientists, believe that changing the charge in court to a more serious one should be initiated exclusively by the prosecution in compliance with provision of the accused's right to defend themselves against a new charge. The proposed procedures for the prosecutor to change the charge to a more serious one directly during the judicial proceedings with the right to present additional evidence to the court are as follows: the criminal case remains under the control of the court and its resolution by non-judicial authorities is excluded; the movement of the criminal case retains a progressive character and, as a result, the terms of the proceedings are significantly reduced; the right of participants in the criminal process to their access to justice is not limited; there is a procedural economy, since there is no need for additional procedural and investigative actions and a retrial of the case; the right of the public prosecutor to freedom of evidence evaluation is being implemented to a greater extent, the objectivity of his position in the case increases; the court is not involved in the exercise of the accusatory function, the principle of adversarial proceedings is not violated; the objectivity and impartiality of the court is ensured to a greater extent.

Among the problems of improving the CPC $\mathrm{RF}$ we should mention replacement of the inquiry in a shortened form, which, both in terms of the length of investigation and volume of evidence collected, does not differ in any way today from the inquiry in the general procedure and even surpasses it in the number of decisions taken by the inquirer. Instead, we propose a protocol form of pre-trial investigation, carried out within 48 hours against a specific person when he is detained red-handed and he/ she recognizes the fact of committing a criminal act. This form of investigation, in our opinion, should not provide for a procedure for initiating a criminal case. It is also suggested to legislatively limit the list of mandatory investigative actions to the interrogation of a person suspected of committing a crime, as well as a victim or witness (in the absence of a victim) of the crime committed. The law should provide for the mandatory detention of such a person for up to
48 hours, during which the investigation must be completed. When a criminal case is brought to court, the period of detention is extended to 72 hours necessary for the trial. Such abridged rules of investigation are present in the norms of the Criminal Procedural Code of Germany, Italy and a number of other European states.

It is worth mentioning that to resolve the relevant problem of returning the power and authority to initiate a criminal case to the prosecutor, it is enough only to change the wording of paragraph 4 of part one of Article 140 of the CPC RF, establishing that "according to the prosecutor's decision to send materials to the investigative body to resolve the issue of criminal prosecution, the investigator, the inquirer immediately (within 24 hours) initiates a criminal case, except in cases that prevent the commencement of its proceedings". Such cases are provided for in part one of Article 24 (paragraphs $3,5,6$ ) and part one of Article 27 of the CPC RF (paragraphs 3-6).

Some representatives of the scientific community [1] put forward a demand for the return the powers to coordinate investigators' appeals to the court about the detention of suspects, accused persons to the prosecutor, since the transfer of this function to the head of the investigative body allegedly led to an increase in violations of the rule of law. Weakness of such judgements is proved by the statistical data, showing a significant reduction in the number of citizens detained annually when these powers were transferred from the prosecutor to the head of the investigative body (Figure 5).

In addition, to prove the necessity of returning to the prosecutor the powers of procedural management of investigators (for objectivity, it should be pointed out that the Prosecutor General of the Russian Federation I.V. Krasnov stated that these rights were sufficient to ensure an adequate investigation supervision level), representatives of the scientific community often put forward the thesis that investigators of both internal affairs bodies and the Investigative Committee of the Russian Federation often ignore the prosecutors' requirements to eliminate violations of federal legislation committed during pre-trial investigation, stipulated by paragraph 3 of part two of Article 37 of the CPC RF.

However, according to the Prosecutor General's Office of Russia (Form 555 of reporting) in 2017-2020 prosecutors in accordance with paragraph 3 of part two of Article 37 of the CPC RF sent to investigators of the Investigative 


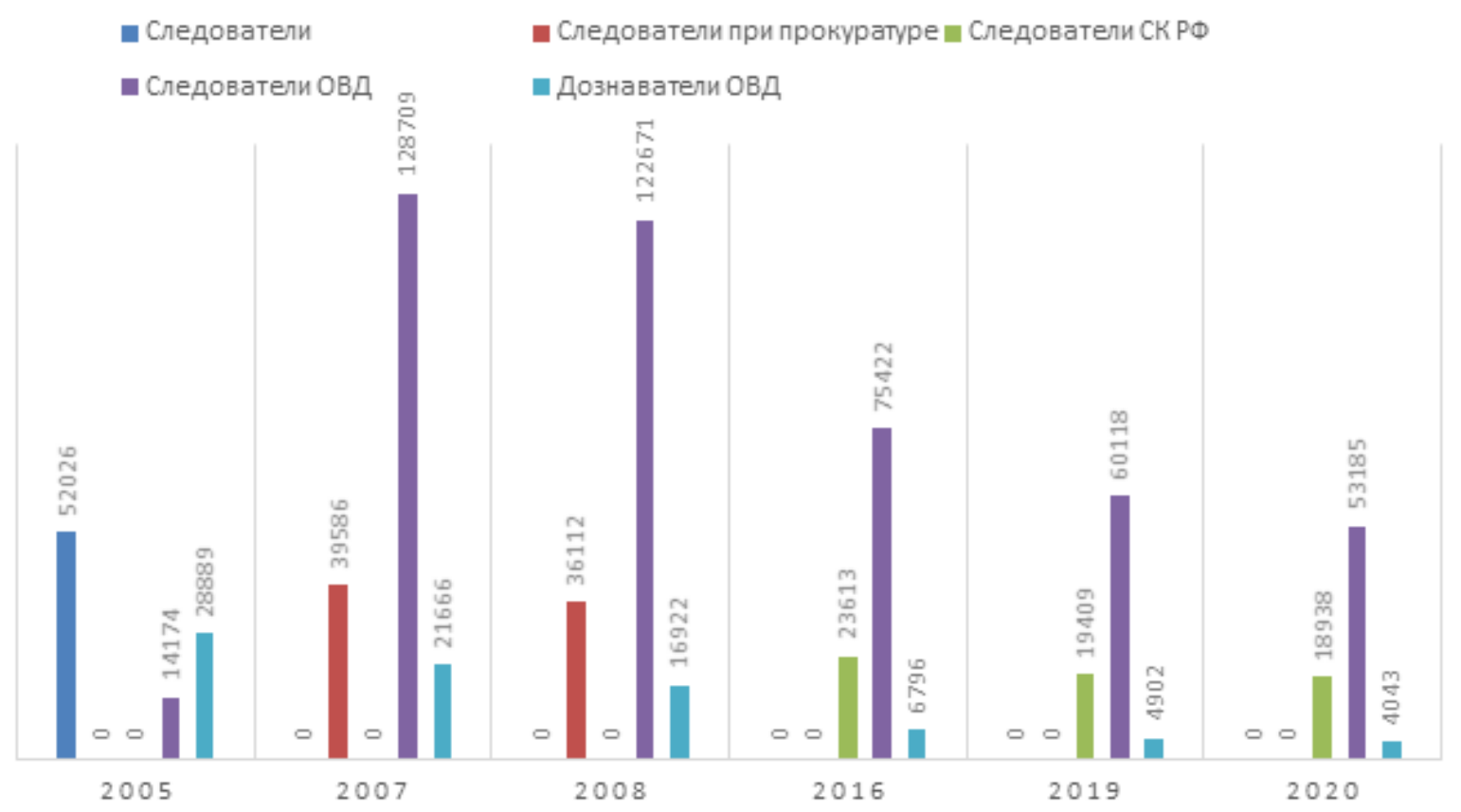

Figure 5. Data on the number of suspects in custody, accused at the request of the investigator, inquirer (for 2005-2008, 2016-2020)

Committee of the Russian Federation 42 thousand-46 thousand claims, of which $97-98 \%$ were satisfied. Of the 105 thousand-125 thousand violations of federal legislation detected by prosecutors during the same period in criminal cases investigated by internal affairs investigators, $99 \%$ of the claims were satisfied. As for inquiry bodies in the system of the Ministry of Internal Affairs of Russia, more than $99 \%$ of such requirements have been met.

Taking into account the factors given in this article and other publications, the author's position [7] consists in a broad discussion in the scientific community and among law enforcement officers, followed by bringing to the legislator proposals providing for the introduction of the considered changes. The task is not to create a new criminal procedural code, but to develop a doctrine of pre-trial proceedings designed to reflect the changes that have taken place in the socio-political, economic and legal life of the Russian state, which today is largely hindered by the stereotype of inviolability of the above-mentioned criminal procedural institutions that do not allow ensuring the effectiveness of criminal proceedings.

\section{REFERENCES}

1. Aleksandrov A.I. Vystuplenie na kruglom stole v Sovete Federatsii 19 noyabrya 2020 g. "Problemy zakonodatel'nogo regulirovaniya pravovogo polozheniya prokurora i advokata ugolovnom protsesse" [Speech at the round table in the Federation Council on November 19, 2020 "Problems of legislative regulation of the legal status of the prosecutor and lawyer in criminal proceedings"]. Available at: http://council.gov.ru/activity/activities/roundtables/?date=19.11.2020 (accessed September 12, 2021).

2. Aleksandrov A.S. On the doctrinal model of criminal procedural evidentiary law of Russia. Vestnik Nizhegorodskoi pravovoi akademii=Bulletin of the Nizhny Novgorod Law Academy, 2015, no. 5 (5), pp. 7-10. (In Russ.).

3. Bozh'ev V.P. "Silent revolution" of the Constitutional Court in the Criminal Process of the Russian Federation. Rossiiskaya yustitsiya=Russian Justice, 2000, no. 10, pp. 9-11. (In Russ.).

4. Bozh'ev V.P., Gavrilov B.Ya. Does the refusal to initiate criminal proceedings correspond to the ideology of modern criminal law policy of Russia. Vestnik Sankt-Peterburgskogo universiteta MVD Rossii=Vestnik of the St. Petersburg University of the Ministry of Internal Affairs of Russia, 2018, no. 2 (78), pp. 74-78. (In Russ.).

5. Vasyukov V.F., Markovicheva E.V. Problemnye voprosy vozbuzhdeniya ugolovnykh del na sovremennom etape: monografiya [Problematic issues of initiation of criminal cases at the present stage: monograph]. Moscow, Prospekt. 2016. $80 \mathrm{p}$.

6. Volevodz A.G. Abolition of the stage of initiation of a criminal case: the price paid. Ugolovnyi protsess=Criminal Proceedings, 2014, no. 1, pp. 80-83. (In Russ.).

7. Voskobitova L.A. Criminal justice as a social technology. Ugolovnoe sudoproizvodstvo=Criminal Judicial Proceeding, 2021, no. 2, pp. 6-17. (In Russ.). 
8. Gavrilov B.Ya. Ideology of the formation of modern pre-trial proceedings. Trudy Akademii upravleniya MVD Rossii=Proceedings of the Academy of Management of the Ministry of Internal Affairs of Russia, 2018, no. 1, pp. 22-28. (In Russ.).

9. Gavrilov B.Ya. Does the modern pre-trial proceedings answer the realities of fighting crime? Akademicheskaya mysl'=Academic Thought, 2019, no. 3 (8), pp. 98-102. (In Russ.).

10. Gavrilov B.Ya. Twenty years of the Russian criminal procedure law: whether it complies with scientific views and requirements of the law enforcement officer. Zakony Rossii. Opyt. Analiz. Praktika=Russian Laws: Experience, Analysis, Practice, 2021, no. 6, pp. 4-14. (In Russ.).

11. Gavrilov B.Ya. Pre-trial proceedings efficiency. Ugolovnoe sudoproizvodstvo=Criminal Judicial Proceeding, 2017, no. 2, pp. 19-26. (In Russ.).

12. Gir'ko S.I. O On certain controversial issues of procedural regulation of new prejudicial procedure. Rossiiskii sledovatel'=Russian Investigator, 2010, no. 15, pp. 14-16. (In Russ.).

13. Golovko L.V. The CPC of the Russian Federation as amended in 2001 as codification: "crystallization effect" or "blurring effect"? Zakony Rossii. Opyt. Analiz. Praktika=Russian Laws: Experience, Analysis, Practice, 2021, no. 6, pp. 3-5. (In Russ.).

14. Kozhokar' V.V. Initiation of legal proceedings: legal position of the Constitutional Court and Supreme Court of the Russian Federation. Trudy Akademii upravleniya MVD Rossii=Proceedings of the Academy of Management of the Ministry of Internal Affairs of Russia, 2015, no. 1, pp. 20-22. (In Russ.).

15. Nikulina T.G. History of the institution of attracting a person as an accused and modern development prospects. Vestnik Udmurtskogo universiteta=Bulletin of Udmurt University. Series Economics and Law, 2010, no. 4, pp. 115-117. (In Russ.) . 16. Rossinskii S.B. Initiation of a criminal case as an autonomous stage Russian criminal procedure: pros and cons. Vestnik Ural'skogo yuridicheskogo instituta MVD Rossii=Bulletin of the Ural Law Institute of the Ministry of the Interior of the Russian Federation, 2021, no. 3, pp. 48-54. (In Russ.).

17. Rossinskii S.B. Discussion about the essence and legal nature of the suspect's detention continues. Aktual'nye problemy rossiiskogo prava=Actual Problems of Russian Law, 2018, no. 6 (91), pp. 134-145. (In Russ.).

18. Rossinskii S.B. Involvement as an accused is the result of the fullest possible investigation of the circumstances of the criminal case. Pravda i zakon=Truth and Law, 2021, no. 3, pp. 69-77. (In Russ.).

19. Rossinskii S.B. The CPC of the Russian Federation: revival of a "high" purpose of the criminal procedure form or "memo" for illiterate law enforcement officers. Zakony Rossii. Opyt. Analiz. Praktika=Russian Laws: Experience, Analysis, Practice, 2021, no. 6, p. 42. (In Russ.).

20. Fedorov A.V. Is there any need for case institution stage in drug-related crimes? Narkokontrol'=Narkokontrol, 2017, no. 1, pp. 3-17. (In Russ.).

21. Shadrin V.S. Fate of the criminal case initiation stage. Zakonnost'=Legality, 2015, no. 1, pp. 47-51. (In Russ.).

\section{INFORMATION ABOUT THE AUTHOR}

BORIS YA. GAVRILOV - Doctor of Sciences (Law), Professor, professor of the Department of Administration of Investigative Bodies of the Academy of Management of the Ministry of Internal Affairs of Russia, Moscow, Russian Federation, ORCID: https://orcid.org/0000-0002-2529-491X, e-mail: profgavrilov@yandex.ru 